
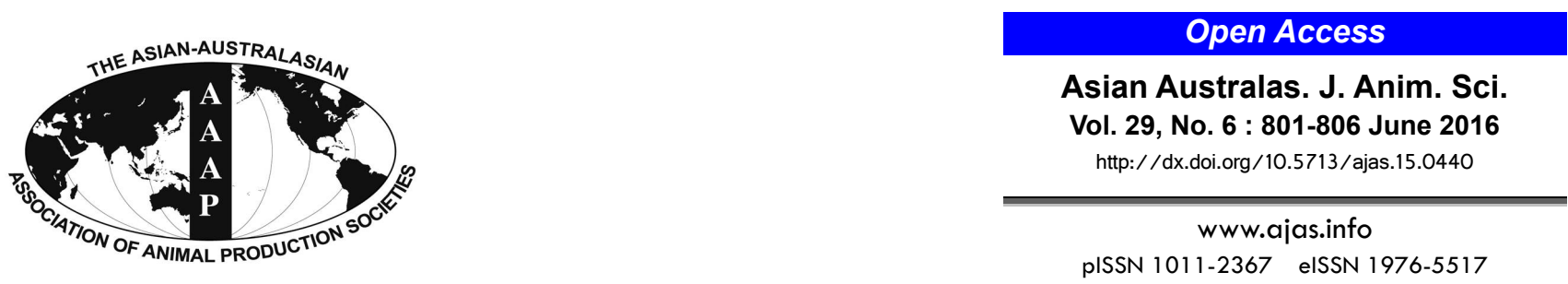

\title{
Effects of Supplemental Levels of Saccharomyces cerevisiae Fermentation Product on Lactation Performance in Dairy Cows under Heat Stress
}

\author{
W. Zhu, B. X. Zhang, K. Y. Yao, I. Yoon ${ }^{1}$, Y. H. Chung, ${ }^{1}$ J. K. Wang, and J. X. Liu* \\ Institute of Dairy Science, College of Animal Sciences, Zhejiang University, Hangzhou 310058, China
}

\begin{abstract}
The objectives of this study were to evaluate the effects of different supplemental levels of Saccharomyces cerevisiae fermentation product (SCFP; Original XP; Diamond V) on lactation performance in Holstein dairy cows under heat stress. Eighty-one multiparous Holstein dairy cows were divided into 27 blocks of 3 cows each based on milk yield (23.6 $\pm 0.20 \mathrm{~kg} / \mathrm{d})$, parity (2.88 \pm 0.91$)$ and day in milk (204 $\pm 46 \mathrm{~d})$. The cows were randomly assigned within blocks to one of three treatments: 0 (control), 120 , or $240 \mathrm{~g} / \mathrm{d}$ of SCFP mixed with 240,120 , or $0 \mathrm{~g}$ of corn meal, respectively. The experiment was carried out during the summer season of 2014 , starting from 14 July 2014 and lasting for 9 weeks with the first week as adaption period. During the experimental period, average daily temperature-humidity index (measured at 08:00, 14:00, and 20:00) was above 68, indicating that cows were exposed to heat stress throughout the study. Rectal temperatures tended to decrease linearly $(\mathrm{p}=0.07)$ for cows supplemented with SCFP compared to the control cows at 14:30, but were not different at 06:30 ( $>0.10)$. Dry matter intake was not affected by SCFP supplementation ( $>0.10)$. Milk yield increased linearly $(\mathrm{p}<0.05)$ with increasing levels of SCFP. Feed efficiency (milk yield/ dry matter intake) was highest $(p<0.05)$ for cows fed $240 \mathrm{~g} / \mathrm{d}$ SCFP. Cows supplemented with SCFP gained $(\mathrm{p}<0.01)$ body weight, while cows in the control lost body weight. Net energy balance also increased linearly $(p<0.01)$ with increasing levels of SCFP. Concentrations of milk urea nitrogen $(p<0.01)$ decreased linearly with increasing levels of SCFP, while no difference $(p>0.10)$ was observed among the treatments in conversion of dietary crude protein to milk protein yield. In summary, supplementation of SCFP alleviated the negative effect of heat stress in lactating Holstein dairy cows and allowed cows to maintain higher milk production, feed efficiency and net energy balance. Effects of SCFP were dose-dependent and greater effects were observed from higher doses. (Key Words: Heat Stress, Saccharomyces cerevisiae, Lactation Performance, Dairy Cow)
\end{abstract}

\section{INTRODUCTION}

Heat stress is detrimental to dairy cows. The comfortable ambient temperatures for dairy cows are between $5^{\circ} \mathrm{C}$ and $25^{\circ} \mathrm{C}$, and a temperature-humidity index (THI) above 68 typically affects dairy production parameters negatively (Burgos-Zimbelman and Collier, 2011). During warm summer months, milk production decreases by $10 \%$ to $35 \%$, which represents a significant cost to the global dairy industry (St-Pierre et al., 2003). The deficit in energy and nutrient availability in heat stressed

\footnotetext{
* Corresponding Author: J. X. Liu. Tel: +86-571-88982097, Fax: +86-571-88982930, E-mail: liujx@zju.edu.cn

${ }^{1}$ Diamond V, Cedar Rapids, IA 52405, USA.

Submitted May 19, 2015; Revised Aug. 13, 2015; Accepted Sept. 6, 2015
}

cows is thought to limit milk production during a thermal load (Shwartz et al., 2009). Methods of increasing digestion efficiency and providing additional energy include supplemental dietary modifiers.

Cows under heat stress are at a higher risk for suboptimal rumen function (Baumgard et al., 2006). Increased respiration rate (causing increased secretion of bicarbonate by the kidneys), reduced feed intake (causing reduced rumination and saliva production) and altered feeding behavior (sorting, slug feeding, etc.) are among the contributing factors (Berman et al., 1985; Collier et al., 2006). Optimizing rumen function of heat stressed cows could mitigate the negative effect of heat stress on lactation performance of dairy cows.

Feed additives such as Saccharomyces cerevisiae 
fermentation product (SCFP; Original XP; Diamond V, Cedar Rapids, IA, USA) are widely used as ruminant fermentation modifiers to optimize rumen health and improve lactation performance in dairy cows. Arambel and Kent (1990) suggested that yeast products might be more effective under heat stress than in normal conditions. Schingoethe et al. (2004) reported a significant improvement in feed efficiency when mid-lactation dairy cows were supplemented with SCFP during summer months. Optimum feeding rate of SCFP may differ under heat stress condition. However, optimum level of supplementary SCFP under heat stress has not been determined.

Therefore, we hypothesized that SCFP would improve lactation performance of dairy cows exposed to heat stress and a higher feeding rate of SCFP could be more effective under such conditions. To address this hypothesis, the effects of different levels of SCFP on dry matter intake (DMI), lactation performance, rectal temperature, and energy status in dairy cows during heat stress were evaluated.

\section{MATERIAL AND METHODS}

\section{Animals, diets, and experimental design}

The use of animals was approved by the Animal Care Committee of Zhejiang University (Hangzhou, China). The experiment was conducted at Hangjiang Dairy farm (Hangzhou, China). Eighty-one multiparous Holstein dairy cows were allocated into 27 blocks based on day in milk (DIM) (204 $\pm 46 ;$ mean \pm standard deviation), parity $(2.88 \pm 0.91)$ and milk yield $(23.6 \pm 0.20 \mathrm{~kg} / \mathrm{d})$. Cows were randomly assigned within block to one of three dietary treatments: 0 (control), 120, or 240 g of SCFP per head per day (Diamond V XP, USA) mixed with 240, 120, or $0 \mathrm{~g}$ of corn meal, respectively (Table 1). The SCFP, a fully fermented yeast culture containing fermentation metabolites, residual yeast cells, and growth media was provided by Diamond V (USA). The supplement was topdressed daily at the time of feeding individually to each cow. Each cow was observed for $20 \mathrm{~min}$ after the feeding to ensure complete consumption of the SCFP. Total mixed ration (TMR) were formulated to meet or exceed the nutrient requirements (MOA, 2004) for lactating Holstein

Table 1. Experimental design

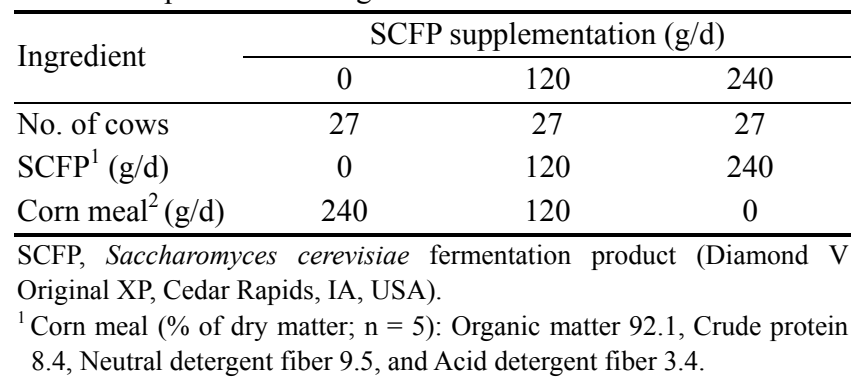

cows weighing $600 \mathrm{~kg}$ and producing $25 \mathrm{~kg} / \mathrm{d}$ of milk. The ingredient and nutrient content of the feed components are presented in Table 2.

Cows were housed in an individual tie-stall barn and fed the TMR daily at 0630,1330 and $2000 \mathrm{~h}$ with free access to drinking water. Feed was offered ad libitum to yield $10 \%$ residues. The barn contained $105-\mathrm{cm}$ diameter fans over feeding alleys every $8 \mathrm{~m}$, and the fans were operated once ambient temperature reached $25^{\circ} \mathrm{C}$. The experiment commenced from July 14 to September 14, 2014, which is the typical hot season in Hangzhou, China. The feeding trial was composed of a 1-week covariate period and 8-week experimental period. Cows were milked 3 times daily at 0700, 1400, and $2030 \mathrm{~h}$. The basal TMR was mixed on site three times daily, with the grain mix prepared every two weeks.

\section{Sampling, measurement, and analyses}

To measure the environmental conditions inside the barn, temperature and relatively humidity $(\mathrm{RH})$ were recorded by calibrated data logging equipment (Ming Gao, Mingle Instruments Co. Ltd., Shenzhen, China) three times

Table 2. Ingredients and chemical composition of basal diets used in the experiment $(\mathrm{n}=8)$

\begin{tabular}{lc}
\hline Items & Contents \\
\hline Ingredient $(\%$ of DM) & 20.7 \\
Corn silage & 12.2 \\
Alfalfa hay & 8.1 \\
Wild ryegrass & 14.2 \\
Ground corn & 4.9 \\
Steam-flaked corn & 4.9 \\
Ground barley & 8.1 \\
Soybean meal & 6.1 \\
Whole cotton seed & 3.2 \\
Cottonseed meal & 2.0 \\
Wheat bran & 4.3 \\
Brewers dried grain & 8.1 \\
Beet pulp & 3.2 \\
Minerals and vitamins ${ }^{1}$ & \\
Chemical composition $(\%$ of DM) & 16.7 \\
$\mathrm{CP}_{\mathrm{NDF}}$ & 36.4 \\
$\mathrm{ADF}$ & 22.6 \\
$\mathrm{Ca}^{2}$ & 0.63 \\
$\mathrm{P}^{2}$ & 0.46 \\
$\mathrm{NE}_{\mathrm{L}}{ }^{2}$ (Mcal/kg DM) & 1.58
\end{tabular}

DM, dry matter; CP, crude protein; NDF, neutral detergent fiber; ADF, acid detergent fiber; $\mathrm{NE}_{\mathrm{L}}$, net energy for lactation.

${ }^{1}$ Formulated to provide (per $\mathrm{kg}$ of DM): $10 \mathrm{~g}$ of CP, $150 \mathrm{~g}$ of EE, $60 \mathrm{~g}$ of crude fiber, $70 \mathrm{~g}$ of Ca, $13 \mathrm{~g}$ of P, $100 \mathrm{~g}$ of salt, $30 \mathrm{~g}$ of Mg, $15 \mathrm{~g}$ of K, 10 $\mathrm{g}$ of Met, $260 \mathrm{mg}$ of $\mathrm{Cu}, 260 \mathrm{mg}$ of Fe, 1,375 mg of Zn, $500 \mathrm{mg}$ of Mn, $112,000 \mathrm{IU}$ of vitamin A, 29,500 IU of vitamin $\mathrm{D}_{3}$, and $700 \mathrm{IU}$ of vitamin E.

${ }^{2}$ Calculated based on Ministry of Agriculture of P.R. China (MOA, 2004). 
daily $(08: 00,14: 00,20: 00)$. Recorders were set at the east and west of the study pen, and placed at a height of $1.9 \mathrm{~m}$ from the floor. Temperature and relative humidity were recorded within $\pm 0.2^{\circ} \mathrm{C}$ and $\pm 2 \%$, respectively. The THI was calculated as: $\mathrm{THI}=$ dew point temperature (TD)- $(0.55-$ $0.55 \mathrm{RH} / 100$ ) (TD-58), where TD was the dry bulb temperature in ${ }^{\circ} \mathrm{F}\left({ }^{\circ} \mathrm{F}=32^{\circ} \mathrm{C}+1.8^{\circ} \mathrm{C}\right)$ and $\mathrm{RH}$ was expressed as a percentage (NOAA, 1976). The average daily temperature and $\mathrm{RH}$ were determined using the recording data, and mean THI were calculated.

Feed offered and residues were weighed on the fourth day of each week to determine the individual DMI throughout the experiment. The representative samples of the TMR, dietary ingredients (corn silage and concentrate mixes) and residues were collected also on the fourth day of every week and stored at $-20^{\circ} \mathrm{C}$ until analyses. All samples were then dried at $60^{\circ} \mathrm{C}$ for 48 hours, ground through a 1 mm-mesh screen (Tecator 1093, Hoganas, Sweden), and stored in closed plastic bottles at room temperature (approximately $25^{\circ} \mathrm{C}$ ) until further analysis. The dry matter, crude protein, and crude ash contents in the test samples (Tables 1 and 2) were determined according to AOAC methods as described by procedures 934.01, 976.05, and 927.02 (AOAC, 2012), respectively. The neutral detergent fiber and acid detergent fiber were determined according to method described by Van Soest et al. (1991).

Cows were milked 3 times daily and individual milk production was recorded daily using a milk-sampling device (Waikato Milking Systems NZ Ltd., Waikato, Hamilton, New Zealand) throughout the experiment. Milk $(50 \mathrm{~mL})$ samples were collected at the second day of each week from each cow at each milking and $0.06 \%$ potassium dichromate was added as the preservative (milk preservative, D\&F Control Systems, San Ramon, CA, USA). Samples from each milking per day were pooled in a proportion of $4: 3: 3$. The samples were send to Shanghai Dairy Herd Improvement testing center (Shanghai, China) for analysis of milk protein, fat, lactose, somatic cell count (SCC), and milk urea nitrogen (MUN) using Combi Foss FT+instrument (Foss Electric, Hillerød, Denmark).

Animal body weights were estimated at the first and last day of the experiment based on the measurement of heart girth and body length using the follow equation: body weight $(\mathrm{BW}, \mathrm{kg})=$ heart $\operatorname{girth}^{2}(\mathrm{~m}) \times$ body length $(\mathrm{m}) \times 90$ (Wang, 2006). Cows were scored for body condition according to Edmonson et al. (1989) using 5-point scale where $1=$ thin and $5=$ fat on the seventh day of the first, fourth, and eighth week by 2 experienced investigators blind to the treatments. The daily mean body condition score (BCS) (average of BCS scores of the two investigators) was used for statistical analysis of BCS.

Rectal temperatures were recorded within $\pm 0.1^{\circ} \mathrm{C}$ on the fifth of each week using clinical veterinary thermometers at
$06: 30$ and $14: 30$

\section{Statistical analysis}

Statistical analyses of data were carried out using SAS software (SAS, 2000). All data except for BW gain were analyzed through the PROC MIXED program of SAS with the covariance type analytical reagent (AR) (1) for repeated measures. A randomized block design with repeated measurements was used, with week, treatment, interaction of treatment $\times$ week and block as the fixed effects. Cow was included as a random effect. Means were separated using the PDIFF option in the LSMEANS statement. Data on BW gain were analyzed using the PROC general linear model of SAS. The statistical model was the same as indicated above except that week and treatment $\times$ week were omitted. Results are reported as the least squares means. Linear and quadratic effects of treatment were tested for all data using orthogonal polynomial contrasts. Significance was considered at $\mathrm{p} \leq 0.05$ and tendency was declared at $0.05<\mathrm{p} \leq 0.10$.

\section{RESULTS AND DISCUSSION}

\section{Environmental temperature-humidity index and rectal temperatures}

The average of mean daily THI during the entire experiment was $76.6 \pm 3.69$. The heat wave was moderate during the second half of the study with decreasing THI (Figure 1). Diurnal variation of THI was not large, with the range from 68 to 86 through all days. Mean daily THI throughout the study was above 68 , which characterizes exposure to heat stress for lactating dairy cows (BurgosZimbelman and Collier, 2011). Even with cooling enhancements such as fans in the experiment barn, there were days when cows showed signs of suffering from heat stress, such as a decreased DMI and lack of movement. Rectal temperatures tended to decrease linearly $(p=0.07)$ with increasing amount of SCFP compared to the control at 14:30, but were not different at 06:30 ( $\mathrm{p}>0.10)$ (Table 3). This suggests that higher dose of SCFP is more effective in alleviating metabolic heat load of a cow during the day when heat stress reached a peak, although mechanism of action is not clear at this time.

\section{Dry matter intake and lactation performance}

Supplementation of SCFP did not affect $(p>0.10)$ the DMI (Table 4). According to Poppy et al. (2012) effect of SCFP supplementation on DMI was dependent on the stage of lactation. Cows with <70 DIM increased DMI with SCFP, while cows with $>70$ DIM decreased DMI (Poppy et al., 2012). In this study, mid to late lactation cows with an average DIM of 204 were used and a numerical decrease in DMI was observed with SCFP supplementation. Similar 


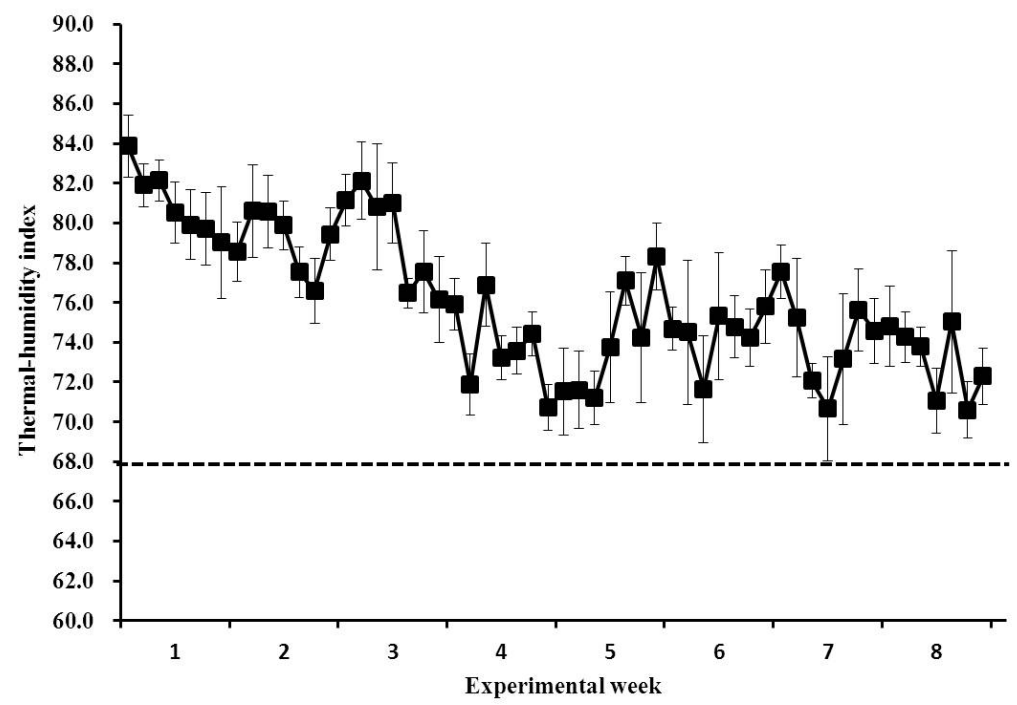

Figure 1. Daily thermal-humidity index (THI) during the trial period (mean \pm standard deviation). The dashed line represents $\mathrm{THI}=68$, when cows are expected to begin suffering heat stress (Burgos-Zimbelman and Collier, 2011).

results were observed when SCFP was supplemented to mid-lactation dairy cows during the summer (Schingoethe et al., 2004).

Milk yield increased linearly $(\mathrm{p}<0.05)$ with increasing levels of SCFP (Table 4), which is in agreement with the results of a meta-analyses by Poppy et al. (2012). Pattern of milk yield was partially attributed to the thermal-humidity index fluctuations (Figure 2). Overall effect as well as effect of SCFP level on milk yield was more pronounced from the fourth to eighth week of the study, suggesting that cows need time to adapt to the supplement before demonstrating significant production response. Although the effect of SCFP on rumen fermentation characteristics was not detected in the present study, and it is likely that the positive responses to SCFP supplementation in milk production resulted from the stabilizing effect on rumen fermentation (Callaway and Martin, 1997). The stabilized rumen condition allows increased growth of fiber-digesting bacteria (Harrison et al., 1988), resulting in improved fiberdigestion and rumen fermentation (Yoon and Garrett, 1998; Mao et al., 2013). Feed efficiency (milk yield/DMI) was highest $(\mathrm{p}<0.05)$ for cows fed $240 \mathrm{~g} / \mathrm{d}$ SCFP. Enhancement of feed efficiency in response to SCFP supplementation was also observed in other studies (Schingoethe et al., 2004; Zhang et al., 2013), and such effects might be attributable to the increased milk production in the SCFP- supplementation cows. Yields of 3.5\% fat-corrected milk and energy corrected milk were not affected $(\mathrm{p}>0.10)$ by SCFP supplementation.

The percentage and yield of milk composition are also presented in Table 4. According to the meta-analysis (Poppy et al., 2012), SCFP-supplementation increased yield of milk fat and protein, while no changes in percentage of milk fat or protein was reported. In the present study, neither milk

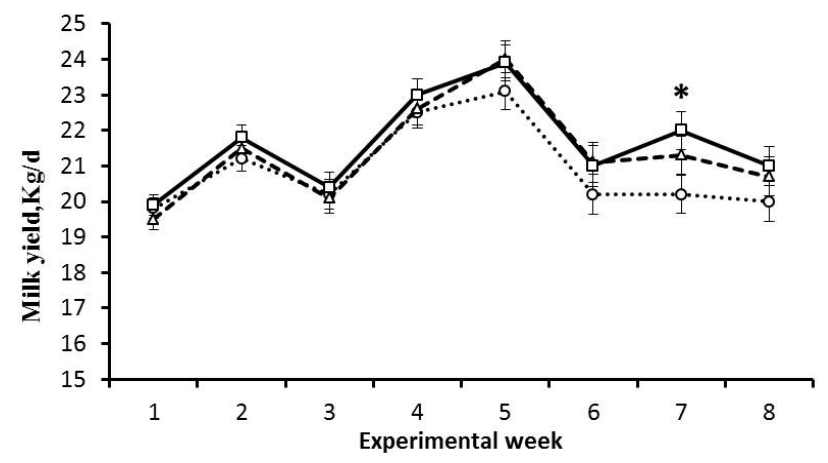

Figure 2. Weekly mean of milk yield of cows during heat stress with supplementation of a Saccharomyces cerevisiae fermentation product (SCFP) at level of $0(\circ), 120(\Delta)$, or $240(\square) \mathrm{g} /$ d. Pattern of milk yield was partially attributed to the thermal-humidity index fluctuations. Bars indicated standard error mean. * In the marked week (week 7), milk yield for cows fed $240 \mathrm{~g} / \mathrm{d}$ SCFP tended to be greater than control cows $(\mathrm{p}=0.07)$.

Table 3. Effect of SCFP supplementation on rectal temperatures in lactation dairy cow during heat stress

\begin{tabular}{|c|c|c|c|c|c|c|c|}
\hline \multirow{2}{*}{ Parameters } & \multicolumn{3}{|c|}{ SCFP supplementation $(\mathrm{g} / \mathrm{d})$} & \multirow{2}{*}{ SEM } & \multicolumn{3}{|c|}{ p-value } \\
\hline & 0 & 120 & 240 & & $\mathrm{~T}$ & $\mathrm{~L}$ & $\mathrm{Q}$ \\
\hline Morning (06:30) & 39.3 & 39.2 & 39.2 & 0.10 & 0.66 & 0.46 & 0.60 \\
\hline Afternoon (14:30) & 39.2 & 39.1 & 38.9 & 0.16 & 0.15 & 0.07 & 0.54 \\
\hline
\end{tabular}

SCFP, Saccharomyces cerevisiae fermentation product (Diamond V Original XP, Cedar Rapids, IA, USA); SEM, standard error of the mean; T, treatment effect; L, linear effect; Q, quadratic effect. 
Table 4. Effect of SCFP supplementation on dry matter intake and lactation performance in dairy cows during heat stress

\begin{tabular}{|c|c|c|c|c|c|c|c|}
\hline \multirow{2}{*}{ Parameters } & \multicolumn{3}{|c|}{ SCFP supplementation $(\mathrm{g} / \mathrm{d})$} & \multirow{2}{*}{ SEM } & \multicolumn{3}{|c|}{ p-value } \\
\hline & 0 & 120 & 240 & & $\mathrm{~T}$ & $\mathrm{~L}$ & Q \\
\hline DMI (kg/d) & 17.2 & 16.9 & 16.9 & 0.23 & 0.60 & 0.33 & 0.77 \\
\hline \multicolumn{8}{|l|}{ Yield (kg/d) } \\
\hline Milk & $20.8^{\mathrm{b}}$ & $21.3^{\mathrm{ab}}$ & $21.5^{\mathrm{a}}$ & 0.19 & 0.04 & 0.02 & 0.50 \\
\hline $3.5 \% \mathrm{FCM}^{1}$ & 24.3 & 24.9 & 24.6 & 0.25 & 0.23 & 0.32 & 0.16 \\
\hline $\mathrm{ECM}^{2}$ & 24.9 & 25.4 & 25.2 & 0.24 & 0.33 & 0.41 & 0.21 \\
\hline Milk protein & 0.718 & 0.722 & 0.718 & 0.0077 & 0.94 & 0.98 & 0.72 \\
\hline Milk fat & 0.939 & 0.973 & 0.955 & 0.0112 & 0.10 & 0.32 & 0.07 \\
\hline \multicolumn{8}{|l|}{ Milk composition $(\%)$} \\
\hline Fat & 4.55 & 4.65 & 4.54 & 0.085 & 0.34 & 0.93 & 0.14 \\
\hline Protein & 3.44 & 3.44 & 3.41 & 0.029 & 0.63 & 0.41 & 0.61 \\
\hline Lactose & 4.77 & 4.74 & 4.80 & 0.019 & 0.18 & 0.43 & 0.09 \\
\hline Total solids & 13.8 & 13.8 & 13.7 & 0.09 & 0.82 & 0.79 & 0.57 \\
\hline $\operatorname{SCC}\left(\times 10^{4}\right) / \mathrm{mL}$ & 19.8 & 22.4 & 21.3 & 2.51 & 0.75 & 0.66 & 0.54 \\
\hline MUN (mg/dL) & $15.5^{\mathrm{a}}$ & $15.3^{\mathrm{a}}$ & $14.6^{\mathrm{b}}$ & 0.21 & 0.02 & $<0.01$ & 0.25 \\
\hline $\mathrm{BW}$ gain $(\mathrm{g} / \mathrm{d})$ & $-13.0^{\mathrm{c}}$ & $17.8^{\mathrm{a}}$ & $11.1^{\mathrm{b}}$ & 0.61 & $<0.01$ & $<0.01$ & $<0.01$ \\
\hline $\mathrm{BCS}$ & $2.82^{\mathrm{b}}$ & $3.05^{\mathrm{a}}$ & $2.84^{\mathrm{b}}$ & 0.071 & 0.04 & 0.83 & 0.01 \\
\hline Feed efficiency ${ }^{3}$ & $1.28^{\mathrm{b}}$ & $1.29^{\mathrm{b}}$ & $1.32^{\mathrm{a}}$ & 0.012 & 0.04 & 0.07 & 0.72 \\
\hline Nitrogen conversion ${ }^{4}$ & 0.269 & 0.272 & 0.275 & 0.0035 & 0.55 & 0.28 & 0.97 \\
\hline Net energy balance $^{5}$ & $2.81^{\mathrm{c}}$ & $3.12^{\mathrm{b}}$ & $4.13^{\mathrm{a}}$ & 0.047 & $<0.01$ & $<0.01$ & $<0.01$ \\
\hline
\end{tabular}

SCFP, Saccharomyces cerevisiae fermentation product (Diamond V Original XP, Cedar Rapids, IA, USA); SEM, standard error of the mean; T, treatment effect; L, linear effect; Q, quadratic effect; DMI, dry matter intake; FCM, fat-corrected milk; ECM, energy corrected milk; SCC, somatic cell count; MUN, milk urea nitrogen; $\mathrm{BW}$, body weight; $\mathrm{BCS}$, body condition score; $\mathrm{NE}_{\mathrm{L}}$, net energy for lactation.

${ }^{1} 3.5 \% \mathrm{FCM}=($ milk kg $\times 0.432)+($ fat $\mathrm{kg} \times 16.216)$ (Dairy Records Management Systems, 2006).

${ }^{2} \mathrm{ECM}=0.3246 \times$ milk yield $(\mathrm{kg})+13.86 \times$ milk fat $(\mathrm{kg})+7.04 \times$ milk protein $(\mathrm{kg})($ Orth, 1992$)$.

${ }^{3}$ Feed efficiency $=$ milk yield/DMI.

${ }^{4}$ Nitrogen conversion $=$ milk protein yield/dietary crude protein intake.

${ }^{5}$ Net energy balance $=\left(\mathrm{DMI} \times \mathrm{NE}_{\mathrm{L}}\right.$ diet $)-\left[\left(0.08 \times \mathrm{BW}^{0.75}\right)+\{(0.0929 \times\right.$ fat $+0.0563 \times$ protein $+0.0395 \times$ lactose $) \times$ milk yield $\left.\}\right](\mathrm{NRC}, 2001)$.

${ }^{\mathrm{a}-\mathrm{c}}$ Means within a row with different superscripts differ $(\mathrm{p}<0.05, \mathrm{n}=27)$.

fat percentage $(\mathrm{p}>0.10)$ nor milk protein percentage ( $\mathrm{p}>0.10)$ was affected by SCFP-supplementation. The positive effect on milk production resulted in $3.6 \%$ greater $(\mathrm{p}=0.10)$ milk fat yield in cows fed $120 \mathrm{~g} / \mathrm{d}$ SCFP than that of the control cows and supported the results reported in the meta-analysis. No differences $(p>0.10)$ among the groups were observed in contents of milk lactose, total solids, and SCC, similar with the results reported by Schingoethe et al. (2004), where the SCFP products were fed to mid-lactation dairy cows during hot season. Concentrations of MUN decreased linearly $(\mathrm{p}<0.01)$ with increasing levels of SCFP, but no difference was observed among the treatments in conversion of dietary $\mathrm{N}$ to milk $\mathrm{N}$. Lower concentration of MUN with $240 \mathrm{~g} / \mathrm{d}$ SCFP supplementation in dairy cows might indicate higher amino acid utilization for productive uses.

\section{Net energy balance}

Cows supplemented with SCFP gained $(\mathrm{p}<0.01) \mathrm{BW}$, but control cows lost BW during the study (Table 4). Body condition score of cows fed $120 \mathrm{~g} / \mathrm{d}$ SCFP were higher $(p<0.05)$ than that of the control cows and cows fed $240 \mathrm{~g} / \mathrm{d}$
SCFP. Net energy balance, calculated based on DMI, milk yield and composition, and estimated BW (NRC, 2001), increased linearly $(p<0.01)$ with increasing levels of SCFP. Improved BW gain, BCS and milk yield without affecting DMI supports the improved net energy balance with SCFP supplementation. Such results in the present study suggest that SCFP supplementation dosage dependently improves dietary energy utilization or absorption in heat-stressed dairy cows.

\section{CONCLUSION}

Supplementation of SCFP alleviated the negative effect of heat stress in lactating Holstein dairy cows and allowed cows to maintain higher milk production, feed efficiency and net energy balance. Effects of SCFP were dosedependent and greater effects were observed from higher doses.

\section{CONFLICT OF INTEREST}

We certify that there is no conflict of interest with any 
financial organization regarding the material discussed in the manuscript.

\section{ACKNOWLEDGMENTS}

This work was supported partly by funds from Diamond V (Cedar Rapids, USA) and from the China Agriculture (Dairy) Research System (CARS-37). The authors gratefully thank the personnel of the Hangjiang Dairy Farm (Hangzhou, China) for their assistance in milking and care of the animals, the members of the Institute of Dairy Science Zhejiang University (Hangzhou, China) for their assistance in the sampling and analysis of the feed stuff.

\section{REFERENCES}

AOAC. 2012. Official Methods of Analysis. 17th edn. Association of Official Analytical Chemists, Arlington, VA, USA.

Arambel, M. J. and B. A. Kent. 1990. Effect of yeast culture on nutrient digestibility and milk yield response in early- to midlactation dairy cows. J. Dairy Sci. 73:1560-1563.

Baumgard, L. H., J. B. Wheelock, and G. Shwartz, M. O'Brien, M. J. VanBaale, R. J. Collier, M. L. Rhoads, and R. P. Rhoads. 2006. Effects of heat stress on nutritional requirements of lactating dairy cattle. In: Proceedings of the 5th Annual Arizona Dairy Production Conference. The University of Arizona Arizona, UT, USA. 8-16.

Berman, A., Y. Folman, M. Kaim, M. Mamen, Z. Herz, D. Wolfenson, A. Arieli, and Y. Graber. 1985. Upper critical temperatures and forced ventilation effects for high-yielding dairy cows in a subtropical climate. J. Dairy Sci. 68:1488-1495.

Burgos-Zimbelman, R. and R. J. Collier. 2011. Feeding strategies for high-producing dairy cows during periods of elevated heat and humidity. Tri-State Dairy Nutrition Conference, Fort Wayne, IN, USA. 111-126.

Callaway, E. S. and S. A. Martin. 1997. Effects of a Saccharomyces cerevisiae culture on ruminal bacteria that utilize lactate and digest cellulose. J. Dairy Sci. 80:2035-2044.

Collier, R. J., G. E. Dahl, and M. J. VanBaale. 2006. Major advances associated with environmental effects on dairy cattle. J. Dairy Sci. 89:1244-1253.

Edmonson, A. J., I. J. Lean, L. D. Weaver, T. Farver, and G. Webster. 1989. A body condition scoring chart for Holstein dairy cows. J. Dairy Sci. 72:68-78.
Harrison, G. A., R. W. Hemken, K. A. Dawson, R. J. Harmon, and K. B. Barber. 1988. Influence of addition of yeast culture supplement to diets of lactating cows on ruminal fermentation and microbial populations. J. Dairy Sci. 71:2967-2975.

Mao, H. L., H. L. Mao, J. K. Wang, J. X. Liu, and I. Yoon. 2013. Effects of Saccharomyces cerevisiae fermentation product on in vitro fermentation and microbial communities of lowquality forages and mixed diets. J. Anim. Sci. 91:3291-3298.

MOA (Ministry of Agriculture, China). 2004. Feeding Standard of Dairy Cattle (NY/T 34-2004). Beijing, China.

NOAA (National Oceanic and Atmospheric Administration). 1976. Livestock hot weather stress. US Dept. Commerce, Natl. Weather Serv. Central Reg., Reg. Operations Manual Lett. C31-76.

NRC (Nutrient Requirents of Dairy Cattle). 2001. Nutrient Requirements of Dairy Cattle. 7th rev. ed. Natl. Acad. Sci. Washington, DC, USA.

Poppy, G. D., A. R. Rabiee, I. J. Lean, W. K. Sanchez, K. L. Dorton, and P. S. Morley. 2012. A meta-analysis of the effects of feeding yeast culture produced by anaerobic fermentation of Saccharomyces cerevisiae on milk production of lactating dairy cows. J. Dairy Sci. 95:6027-6041.

SAS Institute. 2000. SAS User's Guide. Statistics, Version 8.01. SAS Inst., Inc., Cary, NC, USA.

Schingoethe, D. J., K. N. Linke, K. F. Kalscheur, A. R. Hippen, D. R. Rennich, and I. Yoon. 2004. Feed efficiency of midlactation dairy cows fed yeast culture during summer. J. Dairy Sci. 87:4178-4181.

Shwartz, G., M. L. Rhoads, M. J. VanBaale, R. P. Rhoads, and L. H. Baumgard. 2009. Effects of a supplemental yeast culture on heat-stressed lactating Holstein cows. J. Dairy Sci. 92:935-942.

St-Pierre, N. R., B. Cobanov, and G. Schnitkey. 2003. Economic losses from heat stress by US livestock industries. J. Dairy Sci. 86 (E Suppl.):E52-E77.

Van Soest, P. J., J. B. Robertson, and B. A. Lewis. 1991. Methods for dietary fiber, neutral detergent fiber, and nonstarch polysaccharides in relation to animal nutrition. J. Dairy Sci. 74:3583-3597.

Wang, J. Q. 2006. Modern Dairy Production Science. China Agricultural Press, Beijing, China. (In Chinese).

Yoon, I. and J. E. Garrett. 1998. Yeast culture and processing effects on 24-hour in situ ruminal degradation of corn silage. Proc. $8^{\text {th }}$ World Conf. Anim. Prod., Seoul, Korea. 1:322-323. Seoul National University, Seoul, South Korea.

Zhang, R. Y., I. Yoon, W. Y. Zhu, and S. Y. Mao. 2013. Effect of Saccharomyces cerevisiae fermentation product on lactation performance and lipopolysaccharide concentration of dairy cows. Asian Australas. J. Anim. Sci. 26:1137-1143. 